\title{
Pengaruh Intellectual Capital, Rate of Growth of Intellectual Capital dan Pengungkapannya terhadap Kinerja Keuangan Perusahaan
}

\author{
Chatarina Setyani Aswojo Putri \\ Manajemen, Universitas Islam Indonesia \\ Nurfauziah \\ Manajemen, Universitas Islam Indonesia \\ nurfauziah@uii.ac.id
}

\begin{abstract}
Abstrak
Penelitian ini bertujuan untuk menguji pengaruh intellectual capital, rate of growth of intellectual capital (ROGIC) dan pengungkapannya terhadap kinerja keuangan perusahaan yang diproksikan dengan return on asset (ROA). Metode yang digunakan untuk mengukur intellectual capital yaitu value added intellectual coefficient (VAIC ${ }^{\mathrm{TM}}$ ). Penelitian ini juga menguji pengaruh dari ketiga komponen intellectual capital (VAIC) yaitu physical capital (value added capital employed - VACA), human capital (value added human capital - VAHU) dan structural capital (value added structural capital - STVA) terhadap kinerja keuangan perusahaan. Penentuan sampel dilakukan menggunakan metode purposive sampling dan diperoleh sampel sebanyak 250 perusahaan jasa yang terdaftar di Bursa Efek Indonesia periode 2013-2017. Teknik analisis data dalam penelitian ini menggunakan analisis regresi berganda dan uji t. Hasil penelitian menunjukkan bahwa intellectual capital (VAIC), VACA dan VAHU berpengaruh positif dan signifikan terhadap kinerja keuangan perusahaan. Sedangkan STVA berpengaruh negatif dan signifikan terhadap kinerja keuangan perusahaan. Serta ROGIC dan ICD tidak berpengaruh terhadap kinerja keuangan perusahaan.
\end{abstract}

Kata Kunci : Intellectual Capital (VAIC), Return on Asset (ROA).

\section{Pendahuluan}

Perekonomian global telah membawa dampak perubahan yang signifikan terhadap perusahaan - perusahaan di Indonesia. Hal ini ditandai dengan berkembangnya ilmu pengetahuan, teknologi yang maju dan persaingan ketat antar perusahaan bahkan perusahaan yang memiliki bidang sejenis. Sehingga setiap dari perusahaan tersebut harus memiliki cara sendiri untuk mempertahankan posisi perusahaan dan penentuan strategi bersaing agar dapat memenangkan persaingan guna mencapai keunggulan kompetitif.

Kunci keberhasilan dalam suatu perusahaan tidak hanya terletak pada kepemilikan asset berwujud (physical capital) dan laporan kinerja keuangan yang diukur dengan rasio - rasio keuangan, tetapi lebih pada kepemilikan asset tidak berwujud seperti pengetahuan yang dimiliki sumber daya manusia dalam perusahaan. Salah satu komponen dari aktiva tidak berwujud yaitu modal intelektual (intellectual capital). Menurut Baroroh (2013), Intellectual Capital merupakan cara untuk memperoleh keunggulan kompetitif dan menjadi komponen yang sangat penting bagi kemakmuran, pertumbuhan dan perkembangan perusahaan di era ekonomi baru berbasis pengetahuan. IC juga dianggap sebagai "pencipta nilai tambah ekonomi (economic value creator)" bagi perusahaan - perusahaan yang berorientasi pada pertumbuhan jangka panjang (Kartika dan Hatane, 2013). 
Perkembangan perusahaan akan bergantung pada pengelolaan modal intelektual yang dilakukan oleh manajemen perusahaan. Sebuah perusahaan yang intensif pengetahuan akan memanfaatkan pengetahuan mereka, inovasi dan reputasi untuk mencapai sukses di pasar (Jose et al., 2010 dalam Bhasin, 2012). Salah satu metode yang digunakan untuk mengukur intellectual capital yaitu metode VAIC ${ }^{\mathrm{TM}}$ (Value Added Intellectual Coefficient). Terdapatnya tiga komponen utama dari metode VAIC ${ }^{\mathrm{TM}}$ adalah physical capital (Value Added Capital Employed), human capital (Value Added Human Capital), dan structural capital (Structural Capital Value Added). Masing-masing dari ketiga komponen tersebut memiliki kontribusi yang berbeda terhadap perusahaan.

Penelitian yang dilakukan oleh Ulum dkk (2008) menyatakan bahwa Intellectual capital berpengaruh positif terhadap kinerja keuangan pada sektor perbankan Indonesia periode 2004 - 2006. Hasil tersebut juga didukung oleh peneliti lainnya seperti Chen et.al. (2005), Fajarini \& Firmansyah (2012), Sirojuddin \& Nazaruddin (2014) dan Faradina \& Gayatri 2016). Sementara itu, penelitian yang dilakukan Santoso (2012) menyatakan bahwa modal intelektual tidak berpengaruh terhadap kinerja keuangan perusahaan besar yang terdaftar di Bursa Efek Indonesia.

Perusahaan yang menerapkan intellectual capital, juga akan melakukan pengungkapan modal intelektual. Menurut Aida \& Rahmawati (2015), Intellectual Capital Disclosure (ICD) merupakan pemberian informasi mengenai modal intelektual yang dimiliki suatu perusahaan yang terdiri dari karyawan, pelanggan, teknologi informasi, proses, penelitian dan pengembangan, dan pernyataan strategi. Tujuan dari pengungkapan tersebut yaitu untuk menunjang reputasi, meningkatkan akuntabilitas serta transparansi (dalam bentuk informasi) dari perusahaan tersebut. Salah satu cara perusahaan dalam menyampaikan informasi modal intelektual yaitu menyusun ke dalam bentuk annual report (laporan tahunan).

Pengungkapan laporan tahunan perusahaan digunakan untuk memenuhi kebutuhan informasi kepada para stakeholder serta dapat meningkatkan kinerja keuangan perusahaan. Jadi, pengungkapan modal intelektual ini diharapkan dapat memberikan sinyal yang positif pada pasar sehingga dapat memberikan keuntungan bagi perusahaan. Dalam mengukur intellectual capital disclosure yaitu dengan menggunakan Indeks pengungkapan modal intelektual yang dikembangkan oleh Bukh dkk (Bukh et al. (2005).

Penelitian yang dilakukan oleh Faradina \& Gayatri (2016) menyatakan bahwa ICD berpengaruh positif terhadap kinerja keuangan perusahaan. Sementara itu, penelitian yang dilakukan oleh Santoso (2012) dan Sirojuddin \& Nazaruddin (2014) menyatakan bahwa ICD tidak berpengaruh terhadap kinerja keuangan perusahaan.

Perusahaan yang digunakan dalam penelitian ini adalah perusahaan jasa yang terdaftar di Bursa Efek Indonesia periode 2013 - 2017. Hal ini didasarkan atas beberapa kondisi. Pertama, dilihat dari pergerakan sektor industri yang dipercaya akan menjadi salah satu tumpuan pertumbuhan ekonomi di tahun 2018, menurut Lembaga Penyelidikan Ekonomi dan Masyarakat Fakultas Ekonomi dan Bisnis Universitas Indonesia memperkirakan pertumbuhan ekonomi mencapai 5,3 persen dengan didorong oleh ekspor minyak sawit mentah (CPO), batu bara dan sektor jasa (sumber: Tempo.co diakses pada tanggal 16 April 2018). Kedua, Perusahaan jasa akan lebih banyak mengandalkan pengetahuan baik fisik maupun intelektual sebagai daya saing untuk mencapai keunggulan yang kompetitif. Dari segi fisik, perusahaan memerlukan produk fisik guna memperlancar proses operasional perusahaan. Sedangkan dari segi intelektual, perusahaan juga membutuhkan kemampuan intelektual sumber daya manusia untuk menciptakan inovasi, ide-ide, kreativitas dan membuat keputusan karena perusahaan jasa sangat berhubungan dengan kepuasan konsumen. Ketiga, pemilihan sampel ini juga mengacu pada penelitian Firer \& Stainbank (2003) dalam Lestari \& Krisnawati (2014), yang 
mengungkapkan bahwa perusahaan yang masuk ke dalam industri high knowledge-based didominasi oleh perusahaan - perusahaan yang bergerak di industri jasa, sehingga penggunaan intellectual capital dalam bisnisnya lebih intensif dibanding perusahaan lainnya.

\section{Landasan Teori dan Pengembangan Hipotesisi}

Menurut Aida dan Rahmawati (2015), pendekatan berbasis sumber daya (resource based view) adalah suatu teori yang dikembangkan untuk menganalisis keunggulan bersaing suatu perusahaan yang menonjolkan pengetahuan atau perekonomian yang mengandalkan asset - asset tak berwujud (intangible assets). Dilihat dari sudut pandang resource based, perusahaan memandang sumber daya perusahaan sebagai pendorong utama daya saing dan kinerja perusahaan. Sumber daya ini mencakup baik tangible asset maupun intangible asset yang telah diinternalisasi oleh perusahaan dan digunakan secara efektif dan efisien untuk menghasilkan strategi kompetitif (Belkaoui, 2002). Oleh karena itu, perusahaan harus menyadari pentingnya pemanfaatan dan pengelolaan intellectual capital, karena IC tersebut merupakan sumber daya berbasis pengetahuan yang dapat menciptakan keunggulan kompetitif bagi perusahaan sehingga perusahaan mampu berdaya saing terhadap para pesaing dan mampu menciptakan value added bagi perusahaan.

Dalam konsep teori ini, para stakeholder memiliki kewenangan untuk mempengaruhi manajemen dalam proses pemanfaatan dan pengelolaan sumber daya yang dimiliki oleh perusahaan baik modal manusia (human capital), aset fisik (capital employed), dan modal struktural (structural capital). Karena hanya dengan pemanfaatan dan pengelolaan sumber daya yang baik maka dapat terciptanya value added bagi perusahaan yang kemudian akan berpengaruh terhadap kinerja keuangan dan nilai perusahaan merupakan orientasi para stakeholder dalam mengintervensi manajemen.

Nilai tambah perusahaan akan terbentuk jika terjadi efisiensi dalam penggunaan capital employed (modal fisik dan modal keuangan) serta efisensi penggunaan modal intelektual, terutama human capital (Santoso 2012). Berikut ini terdapat tiga komponen utama dari metode VAIC ${ }^{\text {TM }}$ adalah:

\section{Physical Capital (Value Added Capital Employed - VACA)}

VACA merupakan indikator dalam penciptaan value added melalui satu unit modal fisik (physical capital atau capital employed). VACA ini diukur dengan tujuan untuk mengetahui bagaimana kemampuan suatu perusahaan dalam mengelola modal fisik secara efisien. Komponen dari capital employed berupa tanah, bangunan, peralatan atau teknologi. Dengan pengelolaan dan pemanfaatan capital asset yang baik, maka perusahaan dapat meningkatkan kinerja keuangan, pertumbuhan perusahaan, dan nilai pasar (Kartika \& Hatane, 2013).

\section{Human Capital (Value Added Human Capital - VAHU)}

VAHU merupakan indikator dalam penciptaan value added yang dihasilkan setiap satu rupiah melalui kontribusi modal manusia (human capital) terhadap perusahaan. VAHU ini diukur dengan tujuan untuk mengetahui bagaimana kemampuan human capital membuat nilai pada perusahaan. Menurut Santoso (2012), Human capital adalah kemampuan dan karakteristik karyawan perusahaan seperti energi, kecerdasan, sikap, komitmen, kreatifitas, kemampuan belajar termasuk knowledge dan berbagai skill yang dimiliki oleh karyawan yang dapat dikontribusikan untuk penciptaan nilai tambah perusahaan. Untuk meningkatkan kemampuan human capital tersebut, perusahaan perlu mengelola dan mengembangkan kompetensi yang dimiliki karyawannya dengan cara memberikan 
program pendidikan dan pelatihan. Selain itu, perusahaan juga dapat memberikan gaji dan tunjangan untuk meningkatkan motivasi karyawan dalam mendukung kinerja keuangan perusahaan.

\section{Structural Capital (Value Added Structural Capital - STVA)}

STVA merupakan indikator dalam penciptaan nilai tambah untuk menghasilkan satu rupiah melalui kontribusi perusahaan terhadap human capital. Menurut Sawarjuwono dan Kadir (2003), Structural capital merupakan kemampuan organisasi atau perusahaan dalam memenuhi proses rutinitas perusahaan dan strukturnya yang mendukung usaha karyawan untuk menghasilkan kinerja intelektual yang optimal serta kinerja bisnis secara keseluruhan. Komponen dari modal struktural meliputi budaya organisasi, struktur organisasi, sistem operasional perusahaan, filosofi manajemen dan semua bentuk intellectual property yang dimiliki perusahaan. Jadi, jika suatu perusahaan memanfaatkan intellectual capital dengan didukung sarana dan prasarana yang dimiliki oleh perusahaan untuk pengimplementasian inovasi dari karyawan, maka akan terciptanya value added bagi perusahaan itu sendiri.

\section{Rate of Growth of Intellectual Capital}

Menurut Sari \& Gunawan (2011) Pertumbuhan adalah dampak atas arus perusahaan dari perubahan operasional perusahaan yang disebabkan oleh peningkatan atau penurunan volume usaha. Pertumbuhan perusahaan bergantung terhadap asset yang dimiliki oleh perusahaan tersebut. Tingkat pertumbuhan biasanya merupakan sinyal positif bagi perusahaan untuk tumbuh dan berkembang. Jika Intellectual Capital menjadi faktor pendorong utama dalam peningkatan competitive advantage maka perusahaan harus mengelola dan meningkatkan modal intelektual agar dapat terus bertahan di pasar global dan nantinya akan berpengaruh terhadap laju pertumbuhan modal intelektual.

\section{Intellectual Capital Disclosure}

Menurut Aida dan Rahmawati (2015), pengungkapan modal intelektual merupakan pemberian informasi mengenai modal intelektual yang dimiliki suatu perusahaan yang berkaitan dengan karyawan, pelanggan, teknologi informasi, proses, penelitian dan pengembangan, dan pernyataan strategi. Informasi modal intelektual yang diungkapkan ke dalam laporan tahunan perusahaan memiliki peran yang cukup besar dalam meningkatkan kinerja keuangan perusahaan (Pulic, 1998). Alat yang digunakan untuk mengukur intellectual capital disclosure yaitu Intellectual capital disclosure index yang dikemukakan oleh Bukh et al. (2005). Indeks pengungkapan modal intelektual tersebut dilakukan dengan cara pemberian skor yang tujuannya untuk mengetahui sejauh mana perusahaan melakukan intellectual capital disclosure di dalam laporan tahunan perusahaan.

\section{a. Signalling Theory}

Menurut Spence (1973) dalam Suhardjanto dan Wardhani (2010), Signalling theory menyatakan bahwa perusahaan dengan kinerja yang tinggi akan menggunakan informasi keuangan untuk mengirim sinyal kepada pasar. Manajer perusahaan lebih termotivasi untuk mengungkapkan intellectual capital sebagai private information secara sukarela (Marisanti \& Kiswara, 2012). Berdasarkan teori ini, sangat penting perusahaan dapat mengirimkan sinyal positif atau informasi berupa disclosure kepada pihak stakeholders, karena perusahaan yang sedang berinvestasi dalam bentuk modal intelektual diharapkan dapat memberikan keuntungan serta dapat meningkatkan reputasi dan kinerja keuangan perusahaan.

\section{b. Legitimacy Theory}

Teori legitimasi saling berhubungan dengan teori stakeholder. Menurut Sirojudin dan Nazaruddin (2014), teori legitimasi menyatakan organisasi secara berkelanjutan 
mencari cara untuk menjamin keberlangsungan bisnis perusahaan berada dalam batas dan norma yang berlaku di masyarakat. Pengungkapan informasi mengenai Intellectual capital dalam laporan tahunan perusahaan dapat digunakan untuk menunjukkan perhatian manajemen terhadap nilai - nilai yang ada di dalam masyarakat yang selanjutnya akan direspon oleh pengakuan masyarakat. Jika pengungkapan tersebut sesuai dengan harapan masyarakat, maka hal tersebut dapat meningkatkan kinerja keuangan perusahaan.

\section{Kinerja Keuangan}

Menurut Maesaroh (2015), kinerja suatu perusahaan dapat diukur melalui penilaian kinerja keuangan yang dilakukan oleh pihak manajemen agar dapat memenuhi kewajibannya terhadap para investor dan juga untuk mencapai tujuan tertentu dari perusahaan. Pengukuran kinerja keuangan yang digunakan dalam penelitian ini adalah Return on Asset (ROA). Return on assets (ROA) merupakan indikator dari rasio profitabilitas yang memperlihatkan bagaimana kemampuan perusahaan dalam melakukan efisiensi penggunaan total asetnya untuk menghasilkan profit atau laba bersih.

\section{Pengaruh Intellectual Capital Terhadap Kinerja Keuangan Perusahaan}

Dilihat dari resource based, perusahaan memandang sumber daya perusahaan sebagai pendorong utama daya saing dan kinerja perusahaan. Sumber daya ini mencakup baik tangible asset maupun intangible asset yang telah diinternalisasi oleh perusahaan dan digunakan secara efektif dan efisien untuk menghasilkan strategi kompetitif (Belkaoui, 2002). Jika modal intelektual dianggap sebagai sumber daya yang terukur untuk peningkatan competitive advantages, maka modal intelektual akan memberikan kontribusi terhadap kinerja keuangan perusahaan. Perusahaan yang mengedepankan competitive advantage akan memiliki peluang untuk meningkatkan laba bersih. Peningkatan laba bersih perusahaan dipengaruhi oleh penggunaan dan pengelolaan aset-aset perusahaan secara efisien. Dengan memperhatikan laba bersih dan pengelolaan aset-aset perusahaan secara efisien maka nilai ROA akan meningkat.

Hal ini dibuktikan dengan penelitian yang dilakukan oleh Chen et.al. (2005), Ulum dkk (2008), Fajarini \& Firmansyah (2012), Sirojuddin \& Nazaruddin (2014) dan Faradina \& Gayatri (2016) yang menunjukkan bahwa intellectual capital berpengaruh positif terhadap kinerja keuangan perusahaan yang diproksikan dengan ROA. Berdasarkan uraian di atas, maka kesimpulan hipotesis dalam penelitian ini adalah: perusahaan.

Hipotesis 1: Intellectual Capital berpengaruh positif terhadap kinerja keuangan

\section{Pengaruh Value Added Capital Employed (VACA) Terhadap Kinerja Keuangan Perusahaan}

VACA ini diukur dengan tujuan untuk mengetahui bagaimana kemampuan suatu perusahaan dalam mengelola modal fisik secara efektif dan efisien. Jadi, jika perusahaan melakukan pengelolaan dan pemanfaatan capital assets secara efektif dan efisien, maka perusahaan dapat meningkatkan kinerja keuangan karena modal yang digunakan berasal dari aset yang dapat memberikan kontribusi pada kemampuan perusahaan dalam menghasilkan laba bersih.

Hal ini dapat dibuktikan dengan penelitan yang dilakukan oleh Chen et.al (2005), Kartika dan Hatane (2013), Hudgins (2014) dan Ozkan et.al. (2017) yang menunjukkan bahwa VACA berpengaruh positif terhadap kinerja keuangan. Berdasarkan uraian di atas, maka kesimpulan hipotesis dalam penelitian ini adalah: 
INOBIS: Jurnal Inovasi Bisnis dan Manajemen Indonesia

Volume 2, Nomor 4, September 2019

Chatarina Setyani Aswojo Putri, Nurfauziah

Hipoteis 1a: Value Added Capital Employed (VACA) berpengaruh positif terhadap kinerja keuangan perusahaan.

\section{Pengaruh Value Added Human Capital (VAHU) Terhadap Kinerja Keuangan Perusahaan}

Perusahaan sangat membutuhkan kemampuan knowledge dan skill yang dimiliki oleh human capital (karyawan) dalam penciptaan nilai tambah agar perusahaan dapat bersaing kompetitif di pasar global. Untuk meningkatkan human capital tersebut, perusahaan perlu mengelola dan mengembangkan kompetensi karyawan serta meningkatkan motivasi karyawan dalam mendukung kinerja perusahaan. Jika karyawan sudah termotivasi maka secara tidak langsung, karyawan tersebut akan memberikan feedback atau kontribusi berupa knowledge dan skill kepada perusahaan dan nantinya juga akan berpengaruh terhadap kinerja keuangan perusahaan.

Hal ini dapat dibuktikan dengan penelitan yang dilakukan oleh Chen et.al (2005) dan Ozkan et.al. (2017) yang menunjukkan bahwa VAHU berpengaruh positif terhadap kinerja keuangan perusahaan. Berdasarkan uraian di atas, maka kesimpulan hipotesis dalam penelitian ini adalah:

Hipoteis 1b: Value Added Human Capital (VAHU) berpengaruh positif terhadap kinerja keuangan perusahaan.

\section{Pengaruh Value Added Structural Capital (STVA) Terhadap Kinerja Keuangan Perusahaan}

Menurut Santoso (2012), structural capital adalah knowledge yang dimiliki perusahaan untuk ditransformasikan oleh human capital sehingga dapat memberikan nilai tambah bagi perusahaan. Seorang karyawan dapat memiliki tingkat intelektualitas yang tinggi jika didukung dengan struktur (sarana dan prasarana) yang dimiliki perusahaan maka juga akan berpengaruh terhadap intelektual karyawan itu sendiri. Dengan tersedianya sarana dan prasarana yang baik dan berkualitas dapat dijadikan sebagai tempat untuk pengimplementasian inovasi dari karyawan. Sebaliknya jika perusahaan memiliki struktur yang buruk maka tidak akan tercapainya kinerja secara optimal. Oleh karena itu, pentingnya sebuah manajemen dalam perusahaan perlu melakukan pengelolaan structural capital yang baik sehingga tidak akan menghambat produktivitas karyawan dalam menghasilkan value added bagi perusahaan serta akan membantu meningkatkan kinerja perusahaan.

Hal ini dapat dibuktikan dengan penelitan yang dilakukan oleh Kartika dan Hatane (2013), Hudgins (2014) dan Ozkan et.al. (2017) yang menunjukkan bahwa STVA berpengaruh positif terhadap kinerja keuangan perusahaan. Berdasarkan uraian di atas, maka kesimpulan hipotesis dalam penelitian ini adalah:

Hipoteis 1c: Value Added Structural Capital (STVA) berpengaruh positif terhadap kinerja keuangan perusahaan.

\section{Pengaruh Rate of Growth of Intellectual Capital (ROGIC) Terhadap Kinerja Keuangan Perusahaan}

Perusahaan yang memanfaatkan atau berinvestasi dalam bentuk Intellectual capital akan cenderung memiliki laju pertumbuhan perusahaan yang lebih baik. Tingkat laju pertumbuhan tersebut merupakan sinyal positif bagi perusahaan untuk tumbuh dan berkembang. Dimana perusahaan telah mengelola dan mengembangkan intellectual capitalnya secara efektif dan efisien. Jika demikian maka akan berpengaruh terhadap tingkat profitabilitas suatu perusahaan. 
Hal ini dapat dibuktikan dengan penelitan yang dilakukan oleh Fajarini dan Firmansyah (2012) yang menunjukkan bahwa ROGIC berpengaruh terhadap kinerja keuangan perusahaan. Berdasarkan uraian di atas, maka kesimpulan hipotesis dalam penelitian ini adalah:

Hipoteis 2: Rate of growth of intellectual capital berpengaruh positif terhadap kinerja keuangan perusahaan.

\section{Pengaruh Intellectual Capital Disclosure Terhadap Kinerja Keuangan Perusahaan}

Menurut Aida dan Rahmawati (2015), pengungkapan modal intelektual merupakan pemberian informasi mengenai modal intelektual yang dimiliki suatu perusahaan yang terdiri dari beberapa bagian, yaitu karyawan, pelanggan, teknologi informasi proses, penelitian dan pengembangan, dan pernyataan strategi. Informasi modal intelektual yang diungkapkan ke dalam laporan tahunan perusahaan memiliki peran yang cukup besar dalam meningkatkan kinerja keuangan perusahaan (Pulic, 1998). Pengungkapan modal intelektual tersebut diharapkan juga memberikan sinyal positif pada pasar, yang nantinya juga akan direspon positif oleh para pemangku kepentingan sehingga dapat memberikan keuntungan dan meningkatkan kinerja perusahaan.

Hal ini dapat dibuktikan dengan penelitan yang dilakukan oleh Faradina dan Gayatri (2016) yang menunjukkan bahwa pengungkapan modal intelektual (ICD) berpengaruh positif terhadap kinerja keuangan perusahaan. Berdasarkan uraian di atas, maka kesimpulan hipotesis dalam penelitian ini adalah:

Hipoteis 3: Intellectual Capital Disclosure berpengaruh positif terhadap kinerja keuangan perusahaan.

\section{Metode Penelitian}

Populasi dalam penelitian ini adalah perusahaan jasa yang terdaftar di Bursa Efek Indonesia yang berjumlah 340 perusahaan jasa. Pengambilan sampel dilakukan dengan menggunakan metode purposive sampling, yaitu pemilihan sampel secara acak dengan menggunakan kriteria-kriteria tertentu. Dari 340 perusahaan tersebut, sampel yang memenuhi kriteria dalam penelitian ini adalah sebanyak 50 perusahaan. Periode pengamatan yang digunakan selama 5 tahun. Jadi, total sampel yang diteliti sebanyak 250 data laporan keuangan tahunan perusahaan jasa.

Jenis data yang digunakan dalam penelitian ini adalah data sekunder. Data tersebut dapat diperoleh dari situs www.idx.co.id, www.sahamok.com dan website resmi perusahaan serta data yang tercantum pada BEI yang terdapat di Pojok Bursa Efek Indonesia Fakultas Ekonomi Universitas Islam Indonesia.

Variabel dependen yang digunakan dalam penelitian ini yaitu Return on Asset (ROA). Menurut Lestari \& Krisnawati (2014) rumus ROA diformulasikan sebagai berikut:

$$
R O A=\frac{\text { Laba bersih setelah pajak }}{\text { Total Aset }}
$$

Variabel independen yang digunakan dalam penelitian ini adalah :

\section{a. Intellectual Capital}

Metode yang digunakan dalam pengukuran intellectual capital yaitu metode VAIC ${ }^{\text {TM }}$ yang telah dikembangkan oleh Pulic (1998). Berikut rumus dan tahapan yang digunakan dalam perhitungan VAIC ${ }^{\text {TM }}$ (Ulum dkk, 2008), sebagai berikut: 


\section{Tahap pertama menghitung Value Added (VA)}

Dimana:

$$
V A=O U T-I N
$$

OUT $=$ Output, menunjukkan total penjualan atau pendapatan lain

IN = Input, menunjukkan total beban atau biaya-biaya lain (selain beban karyawan).

\section{Tahap kedua menghitung Value Added Capital Employed (VACA)}

VACA merupakan indikator dalam penciptaan value added melalui satu unit modal fisik (physical capital atau capital employed).

\section{Dimana:}

$$
V A C A=V A / C E
$$

VACA = Value Added Capital Employed, menunjukkan rasio dari VA terhadap CE $\mathrm{VA}=$ Value Added

$\mathrm{CE}=$ Capital Employed, menunjukkan dana-dana yang tersedia (ekuitas dan laba bersih)

\section{Tahap ketiga menghitung Value Added Human Capital (VAHU)}

VAHU merupakan indikator dalam penciptaan value added yang dihasilkan setiap satu rupiah melalui kontribusi modal manusia (human capital) terhadap perusahaan.

Dimana:

$$
V A H U=V A / H C
$$

VAHU = Value Added Human Capital, menunjukkan rasio dari VA terhadap $\mathrm{HC}$

$\mathrm{VA}=$ Value Added

$\mathrm{HC}=$ Human Capital, menunjukkan beban karyawan.

\section{Tahap keempat menghitung Value Added Structural Capital (STVA)}

STVA merupakan indikator dalam penciptaan nilai tambah untuk menghasilkan satu rupiah melalui kontribusi perusahaan terhadap human capital (karyawan).

$$
S T V A=V A / S C
$$

Dimana:

$\mathrm{SC}$

STVA = Value Added Structural Capital, menunjukkan rasio dari VA terhadap

SC = Structural capital, diperoleh dari VA $-\mathrm{HC}$

\section{Tahap kelima menghitung Value Added Intellectual Coefficient (VAIC ${ }^{\mathrm{TM}}$ )}

Metode VAICTM dirancang secara efektif untuk mengindikasikan kemampuan intelektual organisasi.

$$
V A I C^{\mathrm{TM}}=V A C A+V A H U+S T V A
$$

\section{b. Rate of Growth of Intellectual Capital}

ROGIC merupakan selisih antara nilai intellectual capital dari tahun $\mathrm{t}$ dengan nilai intellectual capital tahun t-1. Berikut rumus ROGIC (Ulum dkk, 2008), sebagai berikut: 
INOBIS: Jurnal Inovasi Bisnis dan Manajemen Indonesia

Volume 2, Nomor 4, September 2019

Chatarina Setyani Aswojo Putri, Nurfauziah

ROGIC $=$ VAIC $_{t}-$ VAIC $_{t-1}$

\section{c. Intellectual Capital Disclosure}

Dalam mengukur intellectual capital disclosure yaitu dengan menggunakan Indeks pengungkapan modal intelektual yang dikembangkan oleh Bukh et.al. (2005). Berikut rumus ICD (Bukh et.al., 2005):

Dimana:

$$
\text { Score }=\frac{\sum d i}{M} \times 100 \%
$$

Score $=$ Indeks pengungkapan modal intelektual (ICD Index $)$

di = Diberi angka 1 jika informasi diungkapkan dalam laporan tahunan dan diberi angka 0 jika informasi tidak diungkapkan dalam laporan tahunan.

$\mathrm{M}=$ Total jumlah item yang diungkapkan (78 item)

\section{Analisis Data dan Pembahasan}

Analisis Statistik Deskriptif

Hasil deskriptif disajikan pada tabel 2.

Tabel 2. Hasil Uji Statistik Deskriptif

\begin{tabular}{|l|c|c|c|c|c|}
\hline & $\mathrm{N}$ & Minimum & Maximum & Mean & Std. Deviation \\
\hline ROA & 250 & 0,0013 & 0,4579 & 0,0606 & 0,0733 \\
\hline VAIC & 250 & $-0,5185$ & 48,1272 & 5,8386 & 4,1615 \\
\hline ROGIC & 250 & $-24,9888$ & 34,9614 & 0,0465 & 3,9010 \\
\hline ICD & 250 & 0,0769 & 0,4744 & 0,3171 & 0,0729 \\
\hline VACA & 250 & 0,0405 & 1,4283 & 0,2606 & 0,1925 \\
\hline VAHU & 250 & 1,0412 & 46,8729 & 3,0460 & 3,9818 \\
\hline STVA & 250 & 1,0218 & 25,2551 & 2,7628 & 2,7397 \\
\hline $\begin{array}{l}\text { Valid } N \\
\text { (listwise }\end{array}$ & 250 & & & & \\
\hline
\end{tabular}

Sumber: Hasil olah data, 2019

Berdasarkan tabel 2 diatas, menunjukkan bahwa variabel ROA memiliki nilai minimum 0,0013, nilai maximum 0,4579, nilai mean 0,0606 dan standar deviasi 0,0733. Kemudian untuk variabel VAIC memiliki nilai minimum -0,5185, nilai maximum 48,1272, nilai mean 5,8386 dan standar deviasi 4,1615. Variabel ROGIC memiliki nilai minimum -24,9888, nilai maximum 34,9614, nilai mean 0,0465 dan standar deviasi 3,9010. Nilai minimum untuk variabel ICD sebesar 0,0769 , nilai maximum 0,4744 , nilai mean 0,3171 dan standar deviasi 0,0729 . Variabel VACA memiliki nilai minimum 0,0405 , nilai maximum 1,4283 , nilai mean 0,2606 dan standar deviasi 0,1925. Variabel VAHU memiliki nilai minimum 1,0412, nilai maximum 46,8729, nilai mean 3,0460 dan standar deviasi 3,9818. Sedangkan variabel STVA memiliki nilai minimum 1,0218, nilai maximum 25,2551, nilai mean 2,7628 dan standar deviasi 2,7397. 
INOBIS: Jurnal Inovasi Bisnis dan Manajemen Indonesia

Volume 2, Nomor 4, September 2019

Chatarina Setyani Aswojo Putri, Nurfauziah

\section{Uji Asumsi Klasik}

a. Uji Normalitas

Hasil uji normalitas disajikan pada tabel 3.

Tabel 3. Hasil Uji Normalitas

\begin{tabular}{|l|c|c|c|}
\hline $\begin{array}{c}\text { Unstandardized } \\
\text { Residual }\end{array}$ & N & Kolmogrov-Smirnov Z & Asymp.Sig. (2-tailed) \\
\hline Model 1 & 250 & 0,417 & 0,995 \\
\hline Model 2 & 250 & 0,931 & 0,352 \\
\hline
\end{tabular}

a. Test distribution is Normal.

b. Calculated from data.

Sumber: Hasil olah data, 2019

Berdasarkan hasil uji Kolmogorov-Smirnov untuk masing-masing variabel dependen dari setiap model pada tabel 3 menunjukkan bahwa nilai Asymp.Sig. (2-tailed) > 0,05 yaitu sebesar 0,995 (model 1) dan 0,352 (model 2) yang berarti data residual berdistribusi normal.

\section{b. Uji Multikolinearitas}

Hasil uji normalitas disajikan pada tabel 4.

Tabel 4. Hasil Uji Multikolinearitas

\begin{tabular}{|l|c|c|}
\hline \multirow{2}{*}{ Model } & \multicolumn{2}{|c|}{ Collinearity Statistics } \\
\cline { 2 - 3 } & Tolerance & VIF \\
\hline 1 (Constant) & 0,859 & 1,164 \\
VAIC & 0,859 & 1,164 \\
ROGIC & 1,000 & 1,000 \\
ICD & & \\
\hline 2 (Constant) & 0,925 & 1,081 \\
VACA & 0,765 & 1,307 \\
VAHU & 0,761 & 1,314 \\
STVA & 0,742 & 1,348 \\
ROGIC & 0,997 & 1,003 \\
ICD & & \\
\hline
\end{tabular}

a. Dependent variabel : ROA

Sumber: Hasil olah data, 2019

Berdasarkan hasil uji multikolinearitas yang disajikan dalam tabel diatas menunjukkan bahwa nilai VIF $<10$ dan mempunyai nilai tolerance $>0,10$. Artinya tidak adanya gejala multikolinearitas dalam setiap model regresi baik model 1 dan model 2. 
INOBIS: Jurnal Inovasi Bisnis dan Manajemen Indonesia

Volume 2, Nomor 4, September 2019

Chatarina Setyani Aswojo Putri, Nurfauziah

\section{c. Uji Heteroskesdastisitas}

Hasil uji normalitas disajikan pada gambar dibawah ini.

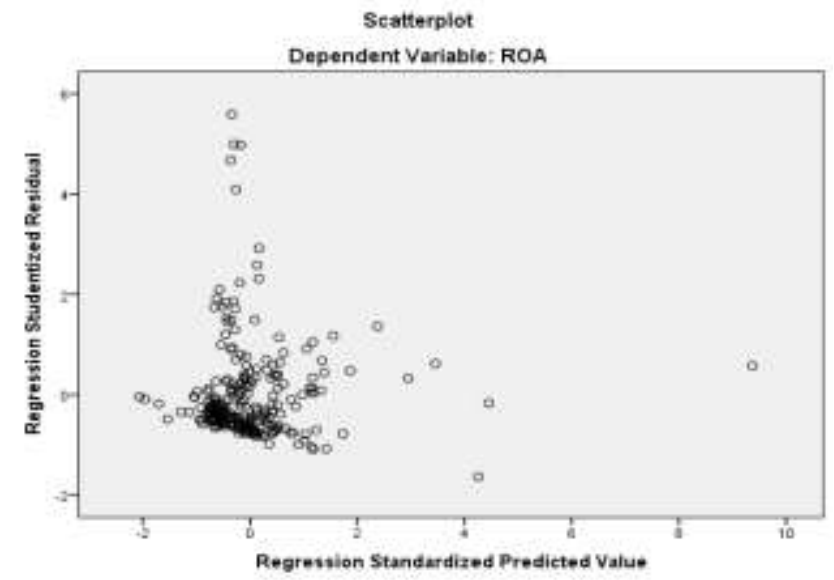

Gambar 1. Grafik Scatterplot Model Regresi 1 (Sumber: Hasil olah data, 2019)

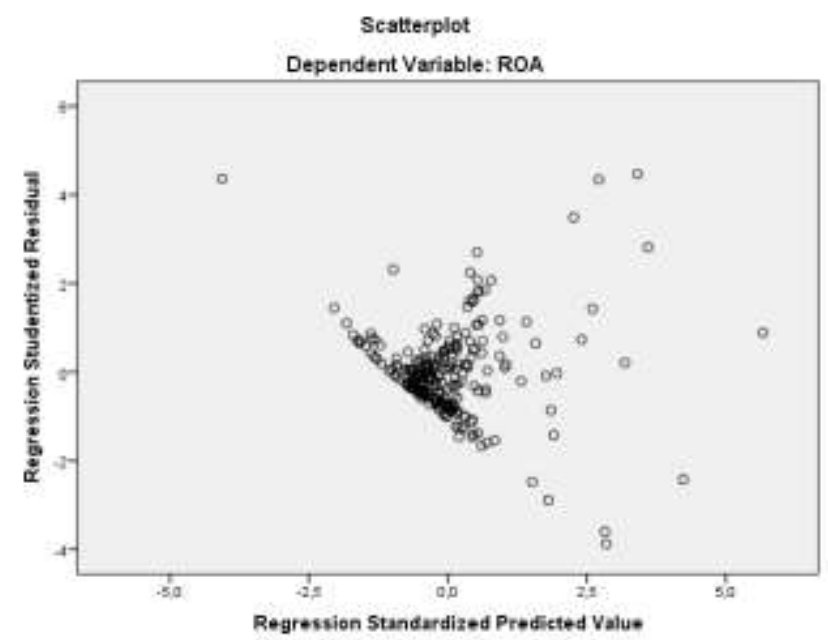

Gambar 2. Grafik Scatterplot Model Regresi 2 (Sumber: Hasil olah data, 2019)

Berdasarkan gambar 1 pada grafik Scatterplot baik model regresi 1 dan 2 menunjukkan bahwa data yang terbentuk dinyatakan tidak adanya gejala heteroskedastisitas. Hal ini terlihat tidak ada pola yang jelas serta titik-titik tersebut menyebar di atas dan di bawah angka 0 pada sumbu Y.

\section{d. Uji Autokorelasi}

Hasil uji normalitas disajikan pada tabel 5.

Tabel 5. Hasil Uji Durbin Watson (DW)

\begin{tabular}{|c|c|}
\hline \multicolumn{1}{|c|}{ Model } & Durbin-Watson \\
\hline 1 & 1,779 \\
\hline 2 & 1,769 \\
\hline
\end{tabular}

a. Model 1 (Constant), ICD, ROGIC, VAIC

Model 2 (Constant), ICD, ROGIC, VACA, STVA, VAHU

b. Dependent variabel : ROA 
Berdasarkan hasil uji durbin watson pada tabel 5 menunjukkan bahwa nilai DW yang dihasilkan berada diantara 1,66 - 2,34 yang berarti tidak adanya gejala autokorelasi dalam setiap model regresi baik model 1 dan model 2.

\section{Analisis Regresi Berganda}

Hasil regresi disajikan pada tabel 6.

Tabel 6. Hasil Uji Regresi Berganda

\begin{tabular}{|l|l|c|c|}
\hline \multirow{2}{*}{ Model } & & \multicolumn{2}{|c|}{ Unstandardized Coefficient } \\
\cline { 3 - 4 } & & B & Std. Error \\
\hline 1 & (Constant) & 0,068 & 0,022 \\
& VAIC & 0,003 & 0,001 \\
& ROGIC & 0,000 & 0,001 \\
& ICD & $-0,079$ & 0,063 \\
\hline 2 & (Constant) & 0,030 & 0,015 \\
& VACA & 0,266 & 0,016 \\
& VAHU & 0,005 & 0,001 \\
& STVA & $-0,010$ & 0,001 \\
& ROGIC & 0,000 & 0,001 \\
& ICD & $-0,087$ & 0,042 \\
\hline
\end{tabular}

a. Dependent variabel : ROA

Sumber: Hasil olah data, 2019

Persamaan regresi dalam penelitian ini adalah:

$$
\begin{aligned}
\text { ROA }= & 0,068+0,003 \text { VAIC }+0,000 \text { ROGIC }-0,079 \text { ICD }+\varepsilon \\
\text { ROA }= & 0,030+0,266 \text { VACA }+0,005 \text { VAHU }-0,010 \text { STVA }+0,000 \text { ROGIC }-0,087 \\
& \text { ICD }+\varepsilon
\end{aligned}
$$

\section{Koefisien Determinasi $\left(\mathbf{R}^{2}\right)$}

Hasil koefisien determinasi $\left(\mathrm{R}^{2}\right)$ disajikan pada tabel 7.

Tabel 7. Hasil Uji Adjusted R-Square

\begin{tabular}{|c|c|c|c|c|}
\hline Model & R & R Square & $\begin{array}{c}\text { Adjusted R } \\
\text { Square }\end{array}$ & $\begin{array}{c}\text { Std. Error of } \\
\text { the Estimate }\end{array}$ \\
\hline 1 & $0,202 \mathrm{a}$ & 0,041 & 0,029 & 0,0721956 \\
\hline 2 & $0,763 \mathrm{a}$ & 0,583 & 0,574 & 0,0478086 \\
\hline
\end{tabular}

a. Model 1 (Constant), ICD, ROGIC, VAIC

Model 2 (Constant), ICD, ROGIC, VACA, STVA, VAHU

b. Dependent variabel : ROA

Sumber: Hasil olah data, 2019

Berdasarkan hasil uji Adjusted R-Square untuk model 1 dapat dilihat bahwa besarnya nilai adjusted R-Square sebesar 0,029 atau 2,9\%. Hal tersebut berarti 2,9\% variasi variabel independen dapat menjelaskan model regresi. Sedangkan sisanya sebesar 0,971 atau 97,1\% 
dijelaskan oleh variabel lain di luar model regresi. Sedangkan, besarnya nilai adjusted RSquare untuk model 2 yaitu sebesar 0,574 atau 57,4\%. Hal tersebut berarti 57,4\% variasi variabel independen dapat menjelaskan model regresi. Sedangkan sisanya sebesar 0,426 atau $42,6 \%$ dijelaskan oleh variabel lain di luar model regresi.

\section{Uji F}

Tabel 8. Hasil Uji F

\begin{tabular}{|l|l|c|c|c|c|c|}
\hline Model & & $\begin{array}{c}\text { Sum of } \\
\text { Squares }\end{array}$ & df & $\begin{array}{c}\text { Mean } \\
\text { Square }\end{array}$ & F & Sig. \\
\hline 1 & Regression & 0,054 & 3 & 0,018 & 3,471 & $0,017 \mathrm{~b}$ \\
& Residual & 1,282 & 246 & 0,005 & & \\
& Total & 1,336 & 249 & & & \\
\hline 2 & Regression & 0,779 & 5 & 0,156 & 68,145 & $0,000 \mathrm{~b}$ \\
& Residual & 0,558 & 244 & 0,002 & & \\
& Total & 1,336 & 249 & & & \\
\hline
\end{tabular}

a. Model 1 (Constant), ICD, VAIC, ROGIC

Model 2 (Constant), ICD, ROGIC, VACA, VAHU, STVA

b. Dependent variabel : ROA

Sumber: Hasil olah data, 2019

Berdasarkan hasil uji $\mathrm{F}$ pada tabel 8 , menunjukkan bahwa nilai signifikansi yang dihasilkan untuk model $1(0,017)$ dan model $2(0,000)<0,05$. Dengan demikian, kedua model regresi tersebut dapat disimpulkan bahwa intellectual capital (VAIC), VACA, STVA, VAHU, ROGIC dan pengungkapan modal intelektual secara bersama-sama berpengaruh terhadap kinerja keuangan perusahaan.

\section{Uji t}

Hasil uji t disajikan pada tabel 9.

Tabel 9. Hasil Uji t

\begin{tabular}{|l|l|l|l|l|}
\hline \multicolumn{1}{|c|}{ Model } & & \multicolumn{1}{c|}{ T } & \multicolumn{1}{c|}{ Sig. } & \multicolumn{1}{c|}{ Keterangan } \\
\hline 1 & (Constant) & 3,135 & 0,002 & \\
& VAIC & 2,629 & 0,009 & Signifikan \\
& ROGIC & 0,292 & 0,771 & Tidak signifikan \\
& ICD & $-1,262$ & 0,208 & Tidak signifikan \\
\hline 2 & (Constant) & 2,022 & 0,044 & \\
& VACA & 16,241 & 0,000 & Signifikan \\
& VAHU & 5,915 & 0,000 & Signifikan \\
& STVA & $-7,652$ & 0,000 & Signifikan \\
& ROGIC & 0,280 & 0,780 & Tidak signifikan \\
& ICD & $-2,080$ & 0,039 & Signifikan \\
\hline
\end{tabular}

a. Dependent variabel: ROA

Sumber: Hasil olah data, 2019

Kesimpulan yang diperoleh dari hasil uji t (parsial) pada tabel di atas, sebagai berikut:

\section{Pengujian $\mathrm{H} 1$}

Hipotesis pertama adalah intellectual capital berpengaruh positif terhadap kinerja keuangan perusahaan. Variabel intellectual capital diproksikan dengan VAIC. Berdasarkan tabel 6 dan 9 variabel VAIC memiliki nilai koefisien regresi positif sebesar 
0,003 dengan nilai signifikansi sebesar 0,009. Koefisien regresi tersebut signifikan pada taraf signifikansi 0,05, karena nilai signifikansi $0,009<0,05$ yang berarti intellectual capital berpengaruh positif dan signifikan terhadap kinerja keuangan perusahaan sehingga hipotesis pertama penelitian ini terbukti.

\section{Pengujian H1a}

Hipotesis ini merupakan komponen dari VAIC. Hipotesis pertama 1a adalah value added capital employed (VACA) berpengaruh positif terhadap kinerja keuangan perusahaan. Berdasarkan tabel 6 dan 9 variabel VACA memiliki nilai koefisien regresi positif sebesar 0,266 dengan nilai signifikansi sebesar 0,000. Koefisien regresi tersebut signifikan pada taraf signifikansi 0,05, karena nilai signifikansi $0,000<0,05$ yang berarti VACA berpengaruh positif dan signifikan terhadap kinerja keuangan perusahaan sehingga hipotesis pertama 1a penelitian ini terbukti.

3. Pengujian H1b

Hipotesis ini merupakan komponen dari VAIC. Hipotesis pertama $1 \mathrm{~b}$ adalah value added human capital (VAHU) berpengaruh positif terhadap kinerja keuangan perusahaan. Berdasarkan tabel 6 dan 9 variabel VAHU memiliki nilai koefisien regresi positif sebesar 0,005 dengan nilai signifikansi sebesar 0,000. Koefisien regresi tersebut signifikan pada taraf signifikansi 0,05 , karena nilai signifikansi $0,000<0,05$ yang berarti VAHU berpengaruh positif dan signifikan terhadap kinerja keuangan perusahaan sehingga hipotesis pertama $1 \mathrm{~b}$ penelitian ini terbukti.

\section{Pengujian H1c}

Hipotesis ini merupakan komponen dari VAIC. Hipotesis pertama 1c adalah value added structural capital (STVA) berpengaruh positif terhadap kinerja keuangan perusahaan. Berdasarkan tabel 6 dan 9 variabel STVA memiliki nilai koefisien regresi negatif sebesar $-0,010$ dengan nilai signifikansi sebesar 0,000. Koefisien regresi tersebut signifikan pada taraf signifikansi 0,05 , karena nilai signifikansi $0,000<0,05$ yang berarti STVA berpengaruh negatif dan signifikan terhadap kinerja keuangan perusahaan sehingga hipotesis pertama 1c penelitian ini tidak terbukti.

\section{Pengujian $\mathrm{H} 2$}

Hipotesis kedua adalah rate of growth of intellectual capital (ROGIC) berpengaruh positif terhadap kinerja keuangan perusahaan. Berdasarkan tabel 6 dan 9 variabel ROGIC memiliki nilai koefisien regresi positif sebesar 0,000 dengan nilai signifikansi sebesar 0,771 . Koefisien regresi tersebut tidak signifikan pada taraf signifikansi 0,05, karena nilai signifikansi 0,771 >0,05 yang berarti ROGIC tidak berpengaruh terhadap kinerja keuangan perusahaan sehingga hipotesis kedua penelitian ini tidak terbukti.

\section{Pengujian $\mathrm{H3}$}

Hipotesis ketiga adalah intellectual capital disclosure (ICD) berpengaruh positif terhadap kinerja keuangan perusahaan. Berdasarkan tabel 6 dan 9 variabel ICD memiliki nilai koefisien regresi negatif sebesar -0,079 dengan nilai signifikansi sebesar 0,208 . Koefisien regresi tersebut tidak signifikan pada taraf signifikansi 0,05, karena nilai signifikansi 0,208 > 0,05 yang berarti ICD tidak berpengaruh terhadap kinerja keuangan perusahaan sehingga hipotesis ketiga penelitian ini tidak terbukti. 


\section{Pembahasan}

\section{Pengaruh Intellectual Capital Terhadap Kinerja Keuangan Perusahaan}

Hasil pengujian hipotesis menunjukkan bahwa intellectual capital berpengaruh positif dan signifikan terhadap kinerja keuangan perusahaan (ROA). Intellectual capital diproksikan dengan VAIC. Hal ini berarti bahwa peningkatan variabel VAIC akan meningkatkan kinerja keuangan perusahaan.

Hasil penelitian ini menunjukkan bahwa intellectual capital telah berperan penting terhadap kinerja keuangan perusahaan. Perusahaan jasa saat ini telah mampu mengelola dan memanfaatkan asset tidak berwujud berupa modal intelektual secara efektif dan efisien guna menghasilkan keuntungan yang lebih besar dan dapat menciptakan value added bagi perusahaan. Penelitian ini konsisten dengan penelitian yang dilakukan oleh Chen et.al. (2005), Ulum dkk (2008), Fajarini \& Firmansyah (2012), Sirojuddin \& Nazaruddin (2014) dan Faradina \& Gayatri (2016) yang menyatakan bahwa Intellectual capital berpengaruh positif dan signifikan terhadap kinerja keuangan perusahaan (ROA).

\section{Pengaruh Value Added Capital Employed Terhadap Kinerja Keuangan Perusahaan}

Hasil pengujian hipotesis menunjukkan bahwa VACA berpengaruh positif dan signifikan terhadap kinerja keuangan perusahaan (ROA). Hal ini berarti bahwa peningkatan variabel VACA akan meningkatkan kinerja keuangan perusahaan.

Hasil penelitian ini menunjukkan bahwa perusahaan jasa telah mampu mengelola physical capital (modal fisiknya) secara efisien. Modal fisik yang dimaksud adalah asset berwujud yang digunakan dalam operasional perusahaan seperti tanah, bangunan, peralatan atau teknologi. Serta telah mengandalkan dana yang tersedia seperti ekuitas dan laba bersih untuk meningkatkan value added perusahaan sehingga dapat meningkatkan kinerja perusahaan. Penelitian ini konsisten dengan penelitian yang dilakukan oleh Chen et.al. (2005), Kartika \& Hatane (2013), Hudgins (2014) dan Ozkan et.al. (2017) yang menyatakan bahwa VACA berpengaruh positif terhadap kinerja keuangan perusahaan (ROA).

\section{Pengaruh Value Added Human Capital Terhadap Kinerja Keuangan Perusahaan}

Hasil pengujian hipotesis menunjukkan bahwa VAHU berpengaruh positif dan signifikan terhadap kinerja keuangan perusahaan (ROA). Hal ini berarti bahwa peningkatan variabel VAHU akan meningkatkan kinerja keuangan perusahaan.

Hasil penelitian ini menunjukkan bahwa perusahaan jasa saat ini tidak hanya mengandalkan modal fisik melainkan telah berfokus pada intelektual sumber daya manusia yang dimiliki perusahaan. Perusahaan yang menganggarkan beban karyawan tinggi juga berharap akan mendapatkan value added yang tinggi dari human capitalnya. Oleh karena itu, Perusahaan telah mengelola dan mengembangkan kemampuan intelektual yang dimiliki masing-masing karyawannya dengan cara mengadakan program pelatihan dan pengembangan untuk meningkatkan produktivitas karyawan. Selain mengadakan program tersebut, perusahaan tentunya juga memberikan gaji dan tunjangan untuk meningkatkan motivasi karyawan. Sumber daya manusia yang baik, produktif, professional dan progresif terdapat knowledge dan skill yang dibutuhkan oleh perusahaan karena kedua hal tersebut mempunyai peran yang sangat besar dalam menentukan keberhasilan suatu perusahaan.

Penelitian ini konsisten dengan penelitian yang dilakukan oleh Chen et.al. (2005) dan Ozkan et.al. (2017) yang menyatakan bahwa HCE (human capital efficiency) berpengaruh positif dan signifikan terhadap kinerja keuangan bank. 


\section{Pengaruh Value Added Structural Capital Terhadap Kinerja Keuangan Perusahaan}

Hasil pengujian hipotesis menunjukkan bahwa STVA berpengaruh negatif dan signifikan terhadap kinerja keuangan perusahaan (ROA). Hal ini berarti bahwa perubahan variabel STVA akan mempengaruhi kinerja keuangan perusahaan.

Hasil penelitian ini menunjukkan bahwa structural capital hanya didefinisikan sebagai proses rutinitas perusahaan dalam mendukung usaha karyawan untuk menghasilkan kinerja intelektual yang optimal. STVA hanya diperoleh dengan membagi value added dengan structural capital. Sedangkan untuk memperoleh SC yaitu selisih antara VA dengan HC (human capital - beban karyawan). Jika VA perusahaan tinggi dan beban karyawan yang harus dibayar juga tinggi, maka nilai SC akan meningkat sehingga STVA mengalami penurunan. Jika STVA mengalami penurunan, maka kinerja keuangan perusahaan meningkat. Artinya perusahaan harus meningkatkan penjualan pendapatan dengan memaksimalkan kinerja karyawan dan perusahaan diharapkan dapat menekan beban-beban operasional guna mendapatkan laba bersih.

Hasil penelitian ini tidak konsisten dengan penelitian yang dilakukan oleh Kartika \& Hatane (2013), Hudgins (2014) dan Ozkan et.al. (2017) yang menyatakan bahwa STVA secara positif berpengaruh signifikan terhadap kinerja keuangan perusahaan. Sedangkan, penelitian yang dilakukan Chen (2005) menunjukkan bahwa tidak ada pengaruh antara STVA terhadap kinerja keuangan perusahaan.

Pengaruh Rate of Growth of Intellectual Capital Terhadap Kinerja Keuangan Perusahaan Hasil pengujian hipotesis menunjukkan bahwa variabel ROGIC tidak berpengaruh terhadap kinerja keuangan perusahaan (ROA). Hal ini berarti bahwa perubahan variabel ROGIC tidak akan mempengaruhi kinerja keuangan perusahaan.

Hasil penelitian ini menunjukkan bahwa perusahaan jasa belum mengutamakan komponen modal intelektual menjadi suatu asset penting untuk memenangkan kompetisi (competitive advantage), sehingga laju pertumbuhannya masih sulit untuk mengukur kinerja keuangan perusahaan. Penelitian ini tidak konsisten dengan penelitian yang dilakukan oleh Fajarini dan Firmansyah (2012) yang menyatakan bahwa adanya pengaruh laju pertumbuhan (ROGIC) terhadap kinerja keuangan perusahaan masa depan.

\section{Pengaruh Intellectual Capital Disclosure Terhadap Kinerja Keuangan Perusahaan}

Hasil pengujian hipotesis menunjukkan bahwa variabel ICD tidak berpengaruh terhadap kinerja keuangan perusahaan (ROA). Hal ini berarti bahwa perubahan variabel ICD tidak akan mempengaruhi kinerja keuangan perusahaan.

Hasil penelitian ini menunjukkan bahwa perusahaan jasa saat ini dalam mengungkapkan informasi modal intelektualnya ke dalam annual report (laporan tahunan) masih bersifat sukarela. Artinya tidak semua perusahaan mengungkapkan informasi yang berkaitan dengan karyawan, pelanggan, proses, teknologi informasi, R\&D dan pernyataan statement dalam laporan tahunan. Hal tersebut dikarenakan manajer perusahaan tidak ingin kompetitor atau pesaing mengetahui letak keunggulan yang dimiliki perusahaan. Sehingga belum bisa mempengaruhi kinerja keuangan perusahaan. Selain itu, perusahaan dalam memberikan sinyal informasi berupa modal intelektual belum bisa mengurangi asimetri informasi yang ada di dalam perusahaan. Hal tersebut dikarenakan total items yang digunakan untuk mengukur ICD sebanyak 78 items sehingga tidak akan mempengaruhi investor untuk mengetahui detail fundamental perusahaan secara keseluruhan. 
Penelitian ini tidak konsisten dengan penelitian yang dilakukan oleh Faradina dan Gayatri (2016) menunjukkan bahwa intellectual capital disclosure berpengaruh positif terhadap return on asset (ROA).

\section{Kesimpulan}

Berdasarkan hasil penelitian dengan menggunakan analisis regresi berganda dan uji t dapat disimpulkan bahwa intellectual capital berpengaruh positif dan signifikan terhadap kinerja keuangan perusahaan (H1 diterima). Value added capital employed (VACA) berpengaruh positif dan signifikan terhadap kinerja keuangan perusahaan (H1a diterima). Value added human capital (VAHU) berpengaruh positif dan signifikan terhadap kinerja keuangan perusahaan (H1b diterima). Value added structural capital (STVA) berpengaruh negatif dan signifikan terhadap kinerja keuangan perusahaan (H1c ditolak). Rate of growth of intellectual capital (ROGIC) tidak berpengaruh terhadap kinerja keuangan perusahaan (H2 ditolak). Intellectual capital disclosure tidak berpengaruh terhadap kinerja keuangan perusahaan (H3 ditolak).

\section{Daftar Pustaka}

Aida, R, U dan Rahmawati, E., 2015, Pengaruh Modal Intelektual dan Pengungkapannya Terhadap Nilai Perusahaan: Efek Intervening Kinerja Perusahaan, Jurnal Akuntansi \& Investasi, 16(2), 97-109

Baroroh, N., 2013, Analisis Pengaruh Modal Intelektual Terhadap Kinerja Keuangan Perusahaan Manufaktur di Indonesia, Jurnal Dinamika Akuntansi, 5(2), 172-182, ISSN 2085-4277

Belkaoui, A, R., 2002, Intellectual Capital and Firm Performance of U.S. Multinational Firms: A Study of the Resource-Based and Stakeholder Views, Journal of Intellectual Capital, Available at SSRN: http://dx.doi.org/10.2139/ssrn.365580

Bhasin, M, L., 2012, Intellectual Capital Disclosure Scenario; Evidence From A Developing Country, European Journal of Business and Social Sciences, 1(9), 26-45

Bukh, Per Nikolaj et al. 2005. "Disclosure of Information on Intellectual Capital in Danish IPO Prospectuses”. Dalam Accounting, Auditing \& Accountability Journal, 18(6), 713-732.

Chahal, H dan Bakshi, P., 2015, Examining Intellectual Capital and Competitive Advantage Relationship (Role of Innovation and Organizational Learning), International Journal of Bank Marketing, 33(3), 376-399

Chen, M, C., Cheng, S dan Hwang, Y., 2005, An Empirical Investigation of the Relationship between Intellectual Capital and Firm's Market Value and Financial Performance, Journal of Intellectual Capital, 6(2), 159-176

Ervina, M, Abdurahim, A dan Suryanto, R., 2008, Intellectual Capital dan Kinerja Keuangan Perusahaan; Suatu Analisis dengan Pendekatan Partial Least Square, 9(2), 138-158

Faradina, I dan Gayatri., 2016, Pengaruh Intellectual Capital dan Intellectual Capital Disclosure Terhadap Kinerja Keuangan Perusahaan, E-Jurnal Akuntansi Universitas Udayana, 15(2), 1623-1653, ISSN: 2302-8556

Fajarini, I dan Firmansyah, R., 2012, Pengaruh Intellectual Capital Terhadap Kinerja Keuangan Perusahaan (Studi Empiris Perusahaan LQ45), Jurnal Dinamika Akuntansi, 4(1), 1-12, ISSN 2085-4277

Ghozali, I. (2013). Aplikasi Analisis Multivariate dengan Program IBM SPSS 21. Semarang: Universitas Diponegoro.

Hashim, M, J., Osman, I dan Alhabshi, S, M., 2015, Effect of Intellectual Capital on Organizational Performance, Procedia-Social and Behavioral Sciences, 211, 207-214 
Huang, Y dan Wu, J, Y., 2010, Intellectual Capital and Knowledge Productivity: The Taiwan Biotech Industry, Management Decision, 48(4), 580-599

Hudgins, M, R., 2014, The Impact of Intellectual Capital on the Performance of U.S. PropertyCasualty Insurance Companies, Business and Economics Journal, 5(4), 1-6, ISSN:2151-6219

Ikatan Akuntan Indonesia., 2009, ED Pernyataan Standar Akuntansi Keuangan No.19 Tentang Aktiva Tidak Berwujud

Kalkan, A., Bozkurt, O, C dan Arman, M., 2014, The Impact of Intellectual Capital, Innovation, and Organizational Strategies on Firm Performance, Procedia-Social and Behavioral Sciences, 150, 700-707

Kamal, M, H, M., Mat, R, C., Rahim, N, A., Husin, N, dan Ismail, I., 2012, Intellectual Capital and Firm Performance of Commercial Banks in Malaysia, Asia Economic and Financial Review, 2(4), 577-590

Kartika, M dan Hatane, E, S., 2011, Pengaruh Intellectual Capital Pada Profitabilitas Perusahaan Perbankan Yang Terdaftar di Bursa Efek Indonesia Pada Tahun 2007-2011, Business Accounting Review, 1(2), 14-25

Khanqah, V, T., Khosroshahi, M, A dan Ghanavati, E., 2012, An Empirical Investigation of the Impact of Intellectual Capital on Firm's Market Value and Financial Performance: Evidence from Iranian Companies, International Journal Management Business Research, 2(1), 1-12

Lestari, W, A dan Krisnawati A., 2014, Analisis Pengaruh Intellectual Capital Terhadap Kinerja Keuangan Perusahaan Industri Jasa (Non-Keuangan) Yang Terdaftar di Bursa Efek Indonesia Tahun 2010-2013, Eproceedings of Management, 1(3)

Maesaroh., 2015, Pengaruh Modal Intelektual Terhadap Kinerja Keuangan Pada Perusahaan Manufaktur, Jurnal Ilmu \& Riset Akuntansi, 4(11), 1-18

Marisanti dan Kiswara E., 2012, Analisis Hubungan Profitabilitas Terhadap Pengungkapan Intellectual Capital, Diponegoro Journal of Accounting, 1(2), 1-11

Mondal, A., 2016, Measuring the Efficiency and Value of Intellectual Capital in Indian Knowledge Companies, Journal of Commerce and Accounting Research, 5(4), 10-17

Octavia, M, C dan Daljono., 2014, Pengaruh Intellectual Capital Terhadap Kinerja Keuangan, Pertumbuhan, dan Nilai Pasar Perusahaan (Studi Empiris pada Perusahaan Konstruksi, Property \& Real Estate yang Terdaftar di Bursa Efek Indonesia Tahun 2009-2012, Diponegoro Journal of Accounting, 3(3), 1, ISSN: 2337-3806

Ozkan, N., Cakan, S dan Kayacan, M., 2017, Intellectual Capital and Financial Performance: A Study of the Turkish Banking Sector, Borsa Istanbul Review, 17(3), 190-198

Pulic, 1998, Measuring the Performance of Intellectual Potential in Knowledge Economy

Puspitawati, L dan Reza, C, N., 2012, Analisis Pemeringkatan Intellectual Capital Performance dan Pengaruhnya Terhadap Kinerja Keuangan Perbankan (Penelitian pada Perusahaan Perbankan yang Terdaftar di Bursa Efek Indonesia, Jurnal Ekono Insentif Kopwil4, 6(1), 1-9, ISSN: 1907-0640

Santoso, S., 2012, Pengaruh Modal Intelektual dan Pengungkapannya Terhadap Kinerja Perusahaan, Jurnal Akuntansi dan Keuangan, 14(1), 16-31

Sari, I, K dan Gunawan, B., 2011, Intellectual Capital on The Financial Performance and Company Growth, Jurnal Fakultas Ekonomi Universitas Muhammadiyah Magelang, 111

Sawarjuwono, T dan Kadir, A,P., 2003, Intellectual Capital: Perlakuan, Pengukuran, dan Pelaporan (Sebuah Library Research), Jurnal Akuntansi \& Keuangan, 5(1), 35-37 
Shella dan Wedari, L, K., 2016, Intellectual Capital \& Intellectual Capital Disclosure Terhadap Market Performance Pada Perusahaan Publik Indeks LQ-45, Jurnal Akuntansi \& Auditing Indonesia, 20(1), 27-36

Sirojudin, G, A dan Nazaruddin, I., 2014, Pengaruh Modal Intelektual dan Pengungkapannya Terhadap Nilai dan Kinerja Perusahaan, Jurnal Akuntansi dan Investasi, 15(2)

Suhardjanto D dan Wardhani, M., 2010, Praktik Intellectual Capital Disclosure Perusahaan yang Terdaftar di Bursa Efek Indonesia, Jurnal Akuntansi \& Auditing Indonesia, 14(1), $71-85$

Supriatna, N., Triantoro, A dan Rustandi, R, 2013, Pengaruh Intellectual Capital Terhadap Kinerja Keuangan Pada Retail yang Terdaftar di Bursa Efek Indonesia (BEI) Pada Tahun 2009-2011, Jurnal Riset \& Akuntansi Keuangan, 1(1), 23-37

Taliyang, S, M dan Mansor, M., 2014, Intellectual Capital Disclosure and Market Capitalization, International Journal of Business and Social Science, 5(10)

Tan, P,W., Plowman, D dan Hancock, P., 2007, Intellectual Capital and Financial Returns of Companies, Journal of Intellectual Capital, 8(1), 76-95

Tempo.co

Ulum, I., Ghozali, I dan Chariri, A., 2008, Intellectual Capital dan Kinerja Keuangan Perusahaan: Suatu Analisis dengan Pendekatan Partial Least Square, In: Simposium Nasional Akuntansi 11 (SNA 11)

Ulum, I., Ghozali, I dan Purwanto, A., 2014, Intellectual Capital Performance of Indonesian Banking Sector: A Modified VAIC (M-VAIC) Perspective, Asian Journal of Finance \& Accounting, 6(2), 103-123, ISSN: 1946-052X

Widarjono, A. (2013). Ekonometrika Pengantar dan Aplikasinya. Yogyakarta: UPP STIM, YKPN

Zuliyati dan Arya, N., 2011, Intellectual Capital and Company's Financial Performance, Dinamika Keuangan Dan Perbankan, 3(1), 113-125, ISSN: 1979-4878 